\title{
Sulautuva opetus \\ asiantuntijuuden kehittämisessä
}

Artikkeli kuvaa pedagogista kehittämistyötä ammattikorkeakoulun terveyden edistämisen moniammatillisessa koulutusohjelmassa, jossa opiskelijat ovat sosiaali-, kuntoutus- ja hoitotyön ammattilaisia. Pedagogisen kehittämisen tavoitteena oli saada kokemusta sulautuvasta opetuksesta, jonka avulla aikuisopiskelijat pystyvät kuvaamaan oman asiantuntijuutensa taustalla vaikuttavia periaatteita, uskomuksia, kokemuksia ja arvoja käyttöteorian käsitteen kautta. Sulautuvalla opetuksella (blended learning) tarkoitetaan erilaisten oppimisympäristöjen tietoista hyödyntämistä opetuksessa.

\section{LEENA LIIMATAINEN, SOILE PIRKOLA\& HANNA HOPIA}

A tikkelimme kuvaa Jyväskylän ammattikorkeakoulun sosiaali- ja terveysalan ylemmässä ammattikorkeakoulututkinnossa tapahtuvaa pedagogista kehittämistä.

Ylemmät ammattikorkeakoulututkinnot vakinaistettiin vuonna 2005 osaksi suomalaisen duaalimallin mukaista korkeakoulujärjestelmää. Tutkinto tarjoaa ammattikorkeakoulututkinnon suorittaneelle, vähintään kolmen vuoden työkokemuksen omaavalle ammattilaiselle uuden mahdollisuuden kehittää edelleen asiantuntijuuttaan työelämälähtöisesti. Sosiaali- ja terveysalan ylemmän ammattikorkeakoulututkinnon laajuus on 90 opintopistettä ja se suoritetaan yleensä työn ohessa. Ylempään ammattikorkeakoulututkintoon johtavien opintojen yleisenä tavoitteena on antaa opiskelijalle työelämän kehittämisen edellyttämät laajat ja syvälliset tiedot asianomaiselta alalta sekä tarvittavat teoreettiset tiedot asianomaisen alan vaativissa asiantuntija- ja johtamistehtävissä toimimista varten (Levonen 2007; Asetus 423/2005).

Moniammatillisen asiantuntijakoulutuksen keskeinen haaste on auttaa aikuisopiskelijaa tunnistamaan ja kuvaamaan osaamisensa lähtökohtia ja sen eri elementtejä. Aiempi osaaminen toimii yksilöllisen ja yhteisöllisen oppimisprosessin ja asiantuntijuuden kehittymisen lähtökohtana. Oman osaamisen ja asiantuntijuuden tavoitteellinen kehittäminen ei onnistu, jos ei ole tietoinen sen tärkeimmistä elementeistä. Eräs mahdollisuus tehdä näkyväksi asiantuntijuuden osa-alueita on käyttöteorian (Argyris \& Schön 1974) hyödyntäminen oppimisprosessia ohjaavana työkaluna. Käyttöteorian tunnistamis- ja rakentamisprosessissa voidaan hyödyntää sulautuvia oppimismenetelmiä. Tämän artikkelin tavoitteena on kuvata Jyväskylän ammattikorkeakoulun sosiaali- ja terveysalan ylemmässä ammattikorkeakoulututkinnossa tapahtuvaa pedagogista kehittämistyötä. Kuvaamme ja arvioimme, miten ammattilaisten käyttöteoriaa ja sulautuvia oppimisympäristöjä on sovellettu ja hyödynnetty terveyden edistämisen asiantuntijuuden kehittymisen tukemisessa yhden opintojakson, Terveyden edistämisen lähtökohdat ja näyttöön perustuva toiminta, toteutuksessa. Opintojakso on osa Terveyden edistämisen koulutusohjelmaa.

\section{Terveyden edistämisen asiantuntijuus ja käyttöteoria}

Ylempään ammattikorkeakoulututkintoon johtavassa koulutuksessa tavoitteena on tiedon ja osaamisen muuntuminen toiminnaksi ja kyvykkyydeksi, joilla työelämää ja sen tarvitsemia muutoksia viedään eteenpäin. Terveyden edistämisen asiantuntija on sosiaali- ja terveysalan ammattilainen, jolla on laaja-alaiset valmiudet edistää väestön terveyttä ja hyvinvointia julkisella, yksityisellä ja kolmannella sektorilla (Terveyden edistämisen laatusuositus 2006). Terveyden edistämisen asiantuntijuus kehittyy kokemuksellisen, yhteistoimin- 
nallisen ja uudistavan oppimisen kautta teoreettisen tiedon (know what), käytännöllisen tiedon (know how) ja itsesäätelytiedon (metakognitiiviset tiedot ja taidot) vuorovaikutuksen tuloksena. Terveyden edistämisen ammatillisessa asiantuntijuudessa painottuu käytännöllinen tieto. Käytännöllisen tiedon syntyminen edellyttää teoreettisen tiedon kytkeytymistä toimintaan metakognitiivisten itsesäätelytietojen ja -taitojen, erityisesti kriittisen reflektion avulla. Terveyden edistämisen ammatillisen asiantuntijuuden kehittymisessä tietoperustan eri osa-alueiden tulisi rakentua suunnitelmallisesti ja vähitellen integroitua toimivasti yhteen. (Bereiter \& Scardamalia 1993; Tynjälä 1999; Liimatainen 2002.) Terveyden edistämisen asiantuntijuus on jatkuvasti kehittyvää, persoonallista ja sidoksissa erilaisiin toimintaympäristöihin.

Käyttöteoria (theory-in-use) muodostaa ammattilaisten toiminnalle ohjausjärjestelmän tai säännöstön, jonka mukaan tämä toimii työssään (Ojanen 2003). Se rakentuu ihmisen omista kokemuksista, uskomuksista, periaatteista, arvoista sekä käsityksistä työn kohteesta ja tietoperustasta. Ammattilaisilla on yleensä useita eri käyttöteorioita, joita hyödynnetään eri tilanteissa. Käyttöteoriat eivät ole muuttumattomia, vaan kokemukset muokkaavat niitä jatkuvasti, läpi elämän. (Argyris \& Schön 1974.) Käyttöteoria voi olla tiedostettu tai tiedostamaton, ja se yleensä sisältää vaikeasti sanoiksi puettavaa hiljaista tietoa. Ammattilaiset saattavat kuvata käyttöteorian sijasta julkiteoriaa eli tekijöitä, joiden ikään kuin oletetaan tai tiedetään kuuluvan ohjata ammattilaisen toimintaa. Aikuisopiskelijan kohdalla on erityisen haastavaa saada esiin nimenomaan toimintaa ja päätöksentekoa ohjaava käyttöteoria, koska oman toiminnan arvot, periaatteet ja lähtökohdat ovat voineet automatisoitua vuosien kuluessa. Olennaista onkin se, että opiskelija joutuu kyseenalaistamaan omat ajatusmallinsa ja tarkastelemaan toimintaansa reflektiivisesti ja analyyttisesti. Tämänkaltaista reflektioprosessia tukevat erilaiset yhteistoiminnalliset oppimismenetelmät, esimerkiksi ryhmän yhteinen, asian kollektiivinen prosessointi. Reflektioprosessin avulla toimija voi tulla tietoisemmaksi omasta käyttöteoriastaan, mikä mahdollistaa sen muokkaamisen ja uudelleen luomisen. (Kauppinen 2007; Onnismaa 2007.)

Terveyden edistämisen koulutusohjelman opintojakson "Terveyden edistämisen lähtökohdat ja näyttöön perustuva toiminta” tavoitteena oli, että opiskelija arvioi ja kehittää henkilökohtaista käyttöteoriaansa hyvinvoinnin ja terveyden edistämisen osaamisessa alan keskeisten käsitteiden ja teoriaperustan pohjalta. Lisäksi tavoitteena oli, että opiskelija saa valmiudet alan tutkimustiedon ja ammattikäytännön seuraamiseen sekä näyttöön perustuvaan toimintaan. Opintojakson konkreettisena tuotoksena oli oman terveyden edistämisen asiantuntijuuden osa-alueiden kuvaaminen käyttöteorian avulla. Opintojaksolle osallistui yhteensä 30 opiskelijaa: 8 opiskelijaa laajavastuisen hoitotyön asiantuntijan ja 22 opiskelijaa sosiaali- ja terveyspalvelujen moniammatillisen johtamisen ja kehittämisen asiantuntijan suuntautumisvaihtoehdoista. Jokaiselle opiskelijalle oli muodostunut enemmän tai vähemmän tiedostettu oman alansa käyttöteoria, jonka perusteella he työssään toimivat ja tekevät päätöksiä.

\section{Sulautuva opetus käyttöteorian näkyväksi tekemisessä}

Sulautuvalla opetuksella (blended learning) tarkoitetaan erilaisten oppimisympäristöjen tietoista hyödyntämistä opetuksessa (Littlejohn \& Pegler 2007; Stubbs, Martin \& Endlar 2006). Termillä usein kuitenkin tarkoitetaan perinteisten menetelmien yhdistämistä verkko-opetuksen ja -oppimisen mahdollisuuksiin. Sulautuvan opetuksen menetelmien kehittäminen verkossa ei kuitenkaan ole vain teknologisista ratkaisuista päättämistä, vaan se on prosessi, jonka tarkoituksena on varmistaa osaamisen kehittyminen koulutuksen aikana (Bersin 2004). Sulautuva opetus eroaa monimuoto-opetuksesta siten, että siinä tietoisesti otetaan käyttöön erilaiset oppimisympäristöt (ks. kuvio 1), jotka varmistavat ja vahvistavat aikuisopiskelijan oppimista. Monimuoto-opetuksen tavoitteena puolestaan on se, että opiskelijoille tarjotaan erilaisia vaihtoehtoisia tapoja suorittaa laajempi opintokokonaisuus tai koko tutkinto (Opetushallitus 2008). Monimuoto-opetuksessa käytetään siis erilaisia menetelmiä ja työtapoja, mutta sulautuvassa opetuksessa korostuu erilaisten oppimisympäristöjen hyödyntäminen ja integrointi esimerkiksi yhden opintojakson aikana. Tavoitteena on, että opiskelijan osaaminen syvenee suunnitelmallisesti ja tavoitteellisesti koko opintojakson ajan. (Twomey 2004).

Sulautuva opetus on tärkeää erityisesti aikuisopiskelussa. Aikuisopiskelijalla on jo muodos- 
tunut suhteellisen syvään juurtuneet käytännöt ja ajatusmallit, ja oman käyttöteorian purkaminen näkyväksi ei välttämättä ole helppoa. Useiden eri oppimisympäristöjen ja opetusmenetelmien hyödyntäminen tarjoaa erilaisia näkökulmia opittavasta asiasta. Erilaisten ympäristöjen menetelmien käyttöä puoltaa myös se, että opiskelijat oppivat eri tavoin. Aikuisten opetuksessa esimerkiksi verkkoympäristön hyödyntäminen mahdollistaa oppimisen osittaisen vapautumisen ajan ja paikan rajoituksista (Sit, Chung, Chow \& Wong 2004). Vaikka opiskelu ei enää ole sidottu tiettyyn tilaan, rajaa internetyhteyden vaatimus kuitenkin edelleen paikkavalintaa.

Tässä artikkelissa kuvatussa opintojaksossa sulautuva opetus muodostui kontaktiopetuksesta, opiskelusta verkko-oppimisympäristössä, itsenäisestä opiskelusta, yhteistoiminnallisesta oppimisesta Learning Café -menetelmällä sekä reflektiivisestä arvioinnista (vertaispalaute, itsearviointi ja opettajan antama palaute). Kuviossa 1 on havainnollistettu oppimisprosessin tavoitteellista etenemistä, käytettyjä oppimisympäristöjä opetusmenetelmiä sekä opintojakson keskeisiä sisältöjä.

\section{Kontaktiopetus ja opiskelu verkko-oppimisympäristössä}

Opintojakso alkoi orientoivalla kontaktiopetuksella, jossa käsiteltiin yhdessä tehtävien ja keskustelun avulla terveyden edistämiseen, asiantuntijuuteen sekä käyttöteoriaan liittyviä keskeisiä käsitteitä. Kontaktiopetuksen aikana opiskelijat analysoivat ryhmissä omaa käytännön työtään. Tarkoituksena oli etsiä yhdistäviä tekijöitä, ja samalla pohtia sitä, mikä työtä ohjaa ja mihin toiminta perustuu. Opiskelijat eivät olleet aikaisemmin juurikaan käsitteellistäneet omaa toimintaansa, joten vertaisryhmä eli muut opiskelijat toimivat tärkeänä tukena opintojakson alusta alkaen. Lähtökohtana oli, että vain oman toiminnan analyyttisella tarkastelulla ja omien käytänteiden reflektiivisellä purkamisella opiskelijan on mahdollista päästä tasolle, jossa hän pystyy kehittämään ja muuttamaan omaa toimintaansa.

\section{Oman käyttöteorian aukikirjoittami- nen ja vertaispalaute}

Aikuisen oppimisen eräänä lähtökohtana on hänen työ- ja muu elämänkokemuksensa. Malisen

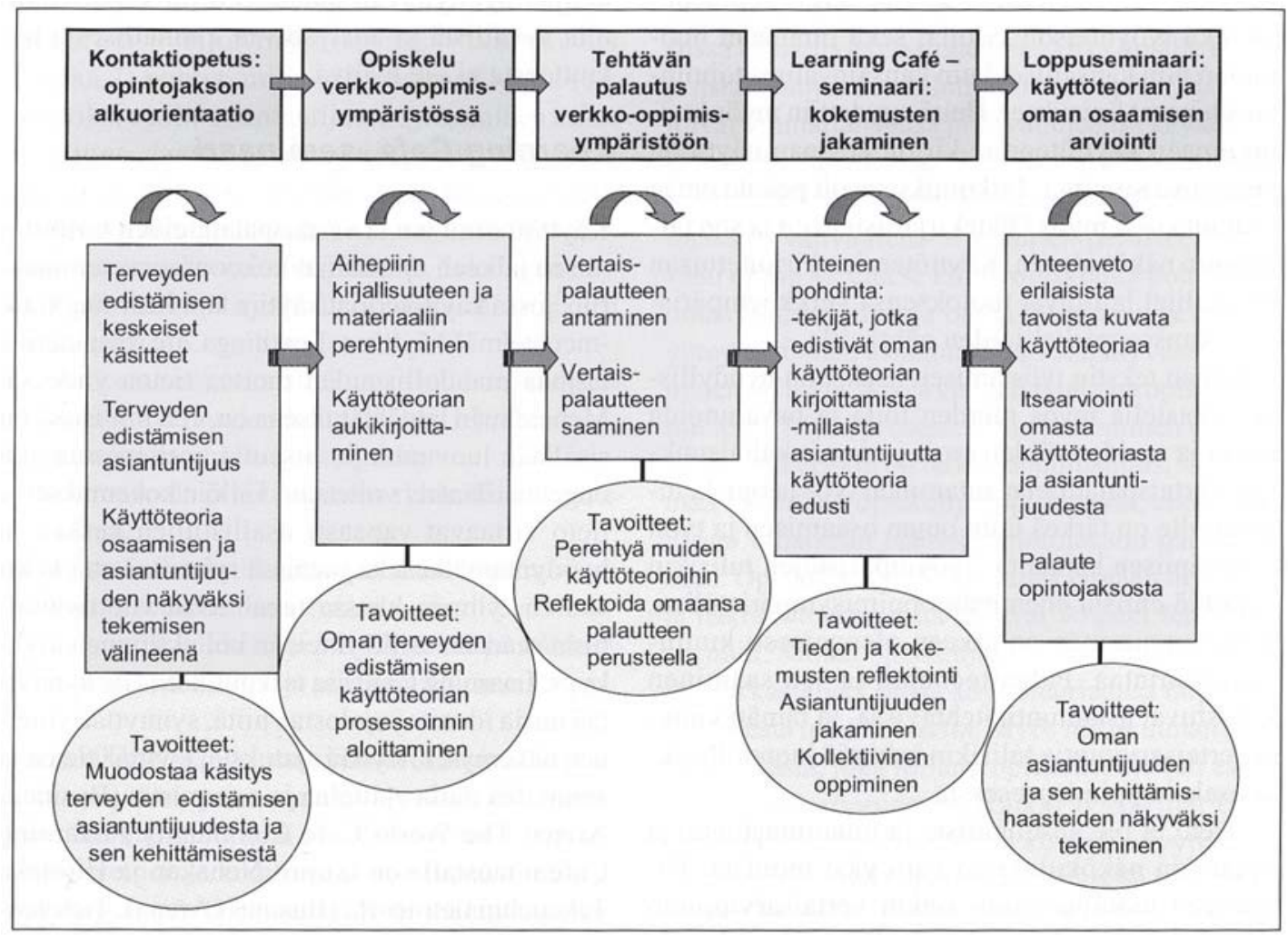

Kuvio 1. Oppimisprosessin ja oppimisympäristöjen kuvaus 
(2000) mukaan tähän kokemukseen täytyy saada syntymään särö, jotta todellista uuden oppimista voisi tapahtua. Särö voi syntyä elämänkokemuksen ja ravistelevan oppimiskokemuksen törmätessä yhteen. Opiskelijan tapa toimia tai ajatella ei välttämättä muutu, jos epäilyä tai säröä ei synny. Oman toiminnan perustan ja lähtökohtien "aukaiseminen” kirjoittamalla saattaa olla vaikeaa pitkään työelämässä olleille. Käyttöteorian näkyväksi tekeminen kirjoittamalla on kuitenkin tärkeää, koska kirjoittamisprosessin aikana opiskelija joutuu jäsentämään ja työstämään omaa asiantuntijuuttaan. Kirjoitettuun dokumenttiin on myös helpompi palata ja tarkastella sitä myös itse kuin ulkopuolisena. Käyttöteorian kirjoittaminen saattaa edistää myös Malisen (2000) mainitseman särön syntymistä opiskelijan ajattelutapaan työstään. Lisäksi kirjoitettu dokumentti on edellytys monien muiden menetelmien hyödyntämiselle käyttöteorian tarkastelussa.

Ensimmäisen kontaktiopiskelukerran jälkeen opiskelijat alkoivat itsenäisesti kirjoittaa omaa käyttöteoriaansa, ja verkko-oppimisympäristössä oli tehtävää tukevaa materiaalia. Käyttöteoriassa opiskelijat tiedostavat toimintaansa ohjaavat lähtökohdat: tutkimustiedon, arvot, periaatteet, kokemuksen, strategiat, visiot. Heitä pyydettiin kirjoittaessa tarkastelemaan toimintaansa oman työnsä sekä työyhteisön tasolla, sekä ottamaan huomioon niin kansalliset kuin kansainväliset toimintaa ohjaavat linjaukset. Heitä pyydettiin myös huomioimaan käyttöteoriaa kirjoittaessaan näyttöön perustuva toiminta. Tarkoituksena oli peilata omaa toimintaansa myös lähdekirjallisuuteen ja sen tarjoamiin näkökulmiin. Käyttöteorian kirjoitettuaan opiskelijat laittoivat tuotoksensa verkkoympäristöön kanssaopiskelijoiden nähtäville.

Oman tekstin työstämisen lisäksi on hyödyllistä tarkastella myös muiden töitä ja havainnoida oman ja muiden töiden eroja ja samankaltaisuuksia. Vertaispalautteen antaminen työ- ja opiskelutovereille on tärkeä taito oman osaamisen ja työn kehittämisen kannalta. Työympäristöjen tulisikin kehittyä entistä enemmän oppimisympäristöiksi, joissa oppiminen on arkeen olennaisesti kuuluvaa toimintaa. Palautteenanto ja sen saaminen korostuvat asiantuntijatehtävissä, ja tämän vuoksi vertaisarviointia tulisikin kehittää luonnolliseksi osaksi oppimisprosessia.

Tieto ei ole absoluuttista ja muuttumatonta, ja opettajan näkökulma on vain yksi monista. Palautteen monipuolisuus onkin vertaisarvioinnin ehdoton hyöty. Tässä kuvatulla opintojaksolla vertaispalaut- teen antamisella pyrittiin toisaalta herättelemään opiskelijoita huomaamaan muiden kriittistenkin palautteiden hyöty, toisaalta harjoiteltiin palautteen antamista. Palautteen toivottiin herättävän opiskelijat pohtimaan vieläkin syvällisemmin omaa käyttöteoriaansa sekä huomaamaan sen heikkouksia ja vahvuuksia. Opiskelijat antoivat toiselleen kirjallista palautetta verkko-oppimisympäristön avulla. Tämä on monelle helpompi väylä kuin kasvotusten - opiskelijoilla on aikaa miettiä mitä sanovat, ja pohdinnoista tulee helposti syvällisempiä kuin luokkatilanteessa. Monet opiskelijat antoivatkin syvällistä palautetta toisilleen. Palautteissa arvioitsijat jatkoivat usein yhden kirjoittajan aloittamaa pohdintaa, tulkiten, selventäen tai yhtyen toisen mielipiteeseen. Verratessaan ja tarkastellessaan kirjallisia töitä, opiskelijat herättelivät kysymyksiä ja osoittivat eroja, joiden avulla heidän ymmärryksenä laajeni ja oppiminen todennäköisesti syveni. Kriittisissä kommenteissa opiskelijat kyseenalaistivat ja osoittivat toisen ajattelun mahdollista juuttumista ja ongelmakohtia. Vertaispalaute on tärkeä elementti oppimisessa, koska samantyyppisessä työssä toimivat opiskelijat näkevät asiat eri tavoin kuin opettaja. Opiskelijaa hyödyttävän palautteen tulee kuitenkin olla syvällistä ja analysoivaa, pinnallisesta palautteesta ei ole hyötyä.

\section{Learning Café -seminaari}

Käyttöteorioiden ja vertaispalautteiden kirjoittamisen jälkeen opiskelijat kokoontuivat seminaariin, jossa käyttöteoriat käytiin läpi Learning Café -menetelmää käyttäen. Learning Café -menetelmä tarjoaa mahdollisuuden tuottaa tietoa yhdessä. Menetelmän lähtöajatuksena on, että ihmisissä on sisällään luovuutta ja viisautta, jota työstämällä ongelmatilanteet voitetaan. Tällöin kokemukset ja tieto virtaavat vapaasti osallistujien kesken ja hyödyntämällä sekä pienissä ryhmissä että koko suuren ryhmän kanssa tapahtuvaa vuorovaikutusta saadaan esille yhteisön kollektiivinen älykkyys. Learning Café:ssa tarkoituksena on synnyttää uusia ideoita ja jalostaa niitä, synnyttää yhteinen näkemys, kiteyttää ajatuksia, levittää tietoa ja synnyttää uutta ajattelua ja osaamista. (Business Arena; The World Café Community.) Learning Café:n taustalla on Ikujiro Nonakan ja Hirotaka Takeuchin tietoteoria (Business Arena). Tietoteorian mukaan tieto eroaa informaatiosta siinä, että tietoon liittyy myös uskomuksia, sitoumuksia, toi- 
mintaa ja merkitystä. Tieto on aina myös kontekstisidonnaista ja suhteellista. Tärkeänä elementtinä Nonakalla ja Takeuchilla on myös ajatus siitä, että tietoa luodaan ihmisten välisessä sosiaalisessa vuorovaikutuksessa, ja he kuvaavat tiedon luomista hiljaisen (tacit) ja eksplisiittisen (explicit) tiedon vuorovaikutuksena. Sosialisaation kautta toisen hiljainen tieto siirtyy myös toisen hiljaiseksi tiedoksi esimerkiksi yhteisten käytänteiden syntymisen kautta, keskustelemalla tai seuraamalla toisen toimintaa. Ulkoistamisen kautta hiljainen tieto saatetaan eksplisiittiseksi. Tähän liittyy usein dialogia ja kollektiivista reflektiota. Eksplisiittistä tietoa voidaan yhdistää, vaihtaa osallistujien kesken. Sisäistäminen on prosessi, jossa eksplisiittinen tieto muunnetaan hiljaiseksi tiedoksi. Siinä opittua käytetään käytännössä, ja tähän läheisesti liittyy "learning by doing”. (Nonaka \& Takeuchi 1995.)

Opintojaksolla opetustila oli järjestetty siten, että opiskelijat istuivat satunnaisessa järjestyksessä neljän hengen pöytäkuntiin. Työskentelyn aluksi kaikki pöydässä olijat esittäytyvät toisilleen, ja valitsivat ryhmästään assistentin. Ryhmillä oli kaksi tehtävää: 1) pohtia, mikä käyttöteorian aukikirjoittamisessa oli vaikeaa ja mitkä tekijät edistivät käyttöteorian näkyväksi tekemistä sekä 2) pohtia, millaista asiantuntijuutta (esimerkiksi rutiiniasiantuntijuus, dynaaminen asiantuntijuus, jaettu asiantuntijuus) käyttöteoriat edustivat ja miksi. Pöydissä oli paperilakanat, joihin ryhmän assistentti kirjasi ryhmän yhteisen tuotoksen molemmista tehtävistä. Jokaiseen pöytään oli lisäksi kirjattu Learning Cafè -etiketti, jonka mukaan osallistujien tuli

- panostaa omaan ajatteluun ja laittaa ajatuksensa jakoon muiden ryhmäläisten hyväksi

- kuunnella yhteisiä oivalluksia

- provosoida ja auttaa muita ryhmäläisiä ajattelemaan

- nostaa olettamukset ja periaatteet esiin

- liittää ryhmän tuottamia ideoita yhteen

- leikitellä, kehitellä ja piirtää, koska pöytäliinoihin kirjoittaminen ja piirtäminen on sallittua

Merkkiäänen kuultuaan ryhmät siirtyivät seuraavaan pöytään, jossa annettiin palautetta toiselle pöytäkunnalle. Ryhmä perehtyi toisten tekemään yhteenvetoon ja kommentoi sitä vapaasti erivärisin tussein pöytälakanalle. Kun jokainen ryhmä oli kiertänyt toistensa pöydät, he palasivat takaisin omaan pöytäänsä. Tällöin tehtävänä oli pereh- tyä muilta ryhmiltä saatuun palautteeseen ja keskustella siitä. Ryhmät tiivistivät omat tuotoksensa ja palautteen yhteen siten, että he nostivat esille molemmista tehtävistä kaksi ydinkiteytystä. Ryhmät kirjoittivat ne fläppipaperille, mitkä kiinnitettiin luokkatilan seinille. Tämän jälkeen pöytäkuntien assistentit kertoivat muille pöytäkuntansa ydinkiteytykset ja koko ryhmänä jatkettiin keskustelua käyttöteoriaan liittyvistä teemoista.

Opintojaksolla Learning Café -menetelmä auttoi keskustelun syntymistä ja tiedon jakamista, vaikka osallistujat toimivat työssään hyvin erilaisissa ympäristöissä. Käyttämällä Learning Café menetelmää opintojaksolla saatiin toteutettua mahdollisimman laajasti jaetun asiantuntijuuden periaatetta. Aikuisopiskelijoille yhteinen tiedon tuottaminen ja asiantuntijuuden jakaminen ovat vahvoja keinoja syventää omaa ajattelua, koska usein aikuisopiskelijoilla on hyvin vahva motivaatio oppia myös muilta ja suhteuttaa omaa ajattelua muiden näkökulmiin.

\section{Opiskelijoiden palautteet opintojaksosta}

Opiskelijoiden arvioinneissa tuli esille opintojaksossa käsiteltyjen asioiden merkitys omalle työlle ja asiantuntijuuden kehittymiselle. Opiskelijat kertoivat ymmärtäneensä ja havainneensa käytännön ja teorian yhteyden, mitä voidaan pitää hyvin vahvana ja tärkeänä oppimistuloksena. Tämän opintojakson vahvuutena arviointien perusteella selvästi olikin se, että se laittoi opiskelijat pohtimaan omaa toimintaansa ja oman toiminnan ja teorian yhteyttä. Oman asiantuntijuuden näkyväksi tekeminen oli myös tärkeä elementti monen opiskelijan mielestä. Myös prosessoinnin jatkuminen opintojakson jälkeenkin oli tärkeä oppimistulos, sillä elämää vartenhan opiskelijat opiskelevat, eikä oppimisen tulisikaan päättyä opintojakson päättymiseen. Opiskelijat arvioivat omaa työtään myös siitä näkökulmasta, mitä olisivat voineet tehdä paremmin. Monet opiskelijat kokivat, että eivät olleet tarkastelleet omaa käyttöteoriaansa tarpeeksi kriittisestä näkökulmasta. Myös näkökulman suppeus oli asia, joka joillain opiskelijoilla tuli esille omaa työtä arvioidessa. Kaikki opiskelijat eivät pohtineet omaa suoritustaan kovin analyyttisesti, jolloin tämä tärkeä oppimiskokemus jäi heiltä saamatta.

Opiskelijoita pyydettiin opintojaksosta kirjallista ja numeerista palautetta. Taulukosta 1 käy ilmi opis- 
kelijoiden vastausten keskiarvot eri osa-alueille. Opiskelijat arvioivat opintojaksoa positiivisesti kaikilla osa-alueilla. Erityisen positiivisiksi opiskelijat arvioivat opintojakson merkityksen omalle ammatilliselle kehittymiselle sekä opintojakson sisällön. Vähiten opiskelijat kokivat kurssista olevan hyötyä heidän opinnäytetyölleen, tosin tässäkin keskiarvo on kuitenkin hyvä.

Palautteissa tuli esille monipuolisesti niin positiivista palautetta siitä, mitä opiskelijat pitivät hyvänä ja toimivana opintojakson sisällöissä ja rakenteessa, kuin myös kehittämisehdotuksia. Omissa arvioinneissaan opiskelijat kertoivat ymmärtäneensä opintojakson asiat ja kokivat opintojakson asiat tärkeiksi. "Opintokokonaisuuden loppua kohden mielenkiintoni vain kasvoi." Opiskelijat kertoivat käyttöteorian laittaneen heidän ajattelemaan asioita. Opiskelijat toivoivat kuitenkin käyttöteorian selkiyttämistä heti kurssin alkaessa. "Aloitusluennot olisivat voineet konkretisoida käsiteltävää aihetta enemmän jotta työn aloitus olisi ollut selkeämpi”. Opiskelijat toivoivat myös enemmän keskustelua käyttöteoriasta. Toisaalta arviointiin liittyen opiskelijat kritisoivat käyttöteorioiden numeerista arviointia. Toivomuksena nousi esiin myös mahdollisuus muokata työtä ja omaa käyttöteoriaa sen läpikäymisen jälkeen, jolloin saatua palautetta pystyisi käyttämään hyödyksi.

Ryhmätyöskentely koettiin miellyttävänä työskentelytapana. Osa opiskelijoista toivoi opetukseen nykyistä enemmän ryhmätyöskentelyä ja kontaktiopetusta, ja palautteissa oli myös toivomus palautteen ja reflektoinnin lisäämisestä. "Ammatillisen kasvuun tukemiseksi tarvittaisiin enemmän tutor-ryhmää yms. palautetta/reflektointia." Monet opiskelijat pitivät Learning Café menetelmää hyvänä ja tarpeellisena, tosin yhdessä palautteessa tätä menetelmää kritisoitiin sen sopivuudesta töiden purkuun. Learning Café menetelmään liittyen esiin nousi myös toive menetelmän toteuttamisesta tutor-ryhmissä. ”Toisten työt tuntemalla olisi saanut syvyyttä lisää keskusteluun”. Palautteissa tuli esiin myös yleisemmin toive muiden opiskelijoiden asiantuntijuuden laajemmasta hyödyntämisestä. Myös huomion kiinnittäminen sisällön tasavertaisuuteen kaikkien opiskelijoiden näkökulmasta tuli esiin.

Opiskelijat kokivat osaavansa liittää tietoa myös omaan työhönsä ja käytännön toimintaan. Omista arvioinneista kävi ilmi, että kirjallinen tehtävä oli koettu hyödylliseksi oman ajattelun kannalta,

\section{Kokonaisarvosana}

Opintojakson haasteellisuus suhteessa opintoviikkomäärään (5= erittäin työllistävä, 1 = ei työllistä riittävästi)

Merkitys omalle ammatilliselle kehitykselle

Hyöty opinnäytetyön kannalta

Oma panos

Kouluttajien toiminta, opetusmuodot ja ohjaus

Oppimateriaalit ja kirjallisuus

Sisältö

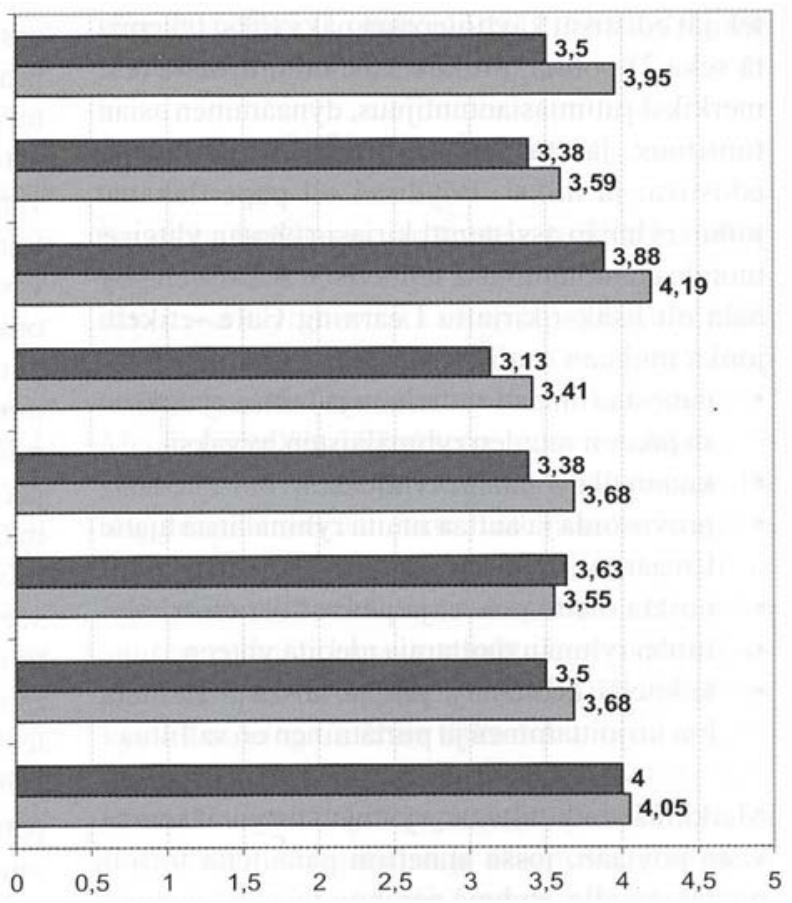

Laajavastuinen ( $M=8)$

Johtaminen $(\mathrm{N}=22)$

Taulukko 1. Opiskelijoiden palaute opintojaksosta Terveyden edistämisen lähtökohdat ja näyttöön perustuva toiminta (1=heikko, 2=välttävä, 3=kohtalainen, 4=hyvä, 5=erinomainen) 
joskin tehtävään toivottiin hieman lisää selkeyttä. Jotkut kokivat kriittisen pohdinnan tehtävää tehdessä olleen hankalaa, joten kriittisen pohdinnan lisääminen opetuksessa ja keskustelussa voisi olla opiskelijoiden omaa ajattelua hyödyttävää. Jotkut kokivat myös käsitteiden ymmärtämisen hankalaksi, joten niiden selventäminen voisi olla tarpeen myös opintojaksolla.

\section{Lopuksi}

Terveyden edistämisen asiantuntijan tulisi osata arvioida ja analysoida terveyden edistämisen monitasoisia ja kompleksisia ongelmia, suunnitella toimivia ratkaisuja ja olla toteutuksen ammattilainen. Heiltä edellytetään kykyä oman ammattialansa kehittämiseen tieteelliseen perusteltavuuteen nojautuen. Tähän tarvitaan ensisijaisesti omaa substanssiosaamista ja tietoisuutta siitä, miten terveyden edistämisen teoria ja käytäntö niveltyvät toisiinsa. Tämä kaikki edellyttää käsitystä siitä, mitkä tekijät ohjaavat asiantuntijan toimintaa ja mihin päätöksenteko erilaisissa tilanteissa perustuu. Tietoisuus omasta käyttöteoriasta on siten peruslähtökohta terveyden edistämisen asiantuntijaksi kehittymisessä.

Kun opiskelijat olivat työstäneet Learning Café -menetelmän kautta käyttöteorioitaan, pidettiin vielä loppuseminaari. Seminaarissa käytiin kokoavasti läpi opintojakson antia ja opiskelijat arvioivat omaa kirjallista työtään ja antoivat palautetta opintojaksosta. Myös opettajat antoivat opiskelijoille palautetta käyttöteorioista. Loppuseminaarissa aikuisopiskelijat tekivät laadullisen ja numeerisen itsearvioinnin omasta käyttöteoriastaan vertaamalla sitä tehtävästä annettuihin arviointikriteereihin. Kriteerit olivat opiskelijoilla käytössä opintojakson alusta alkaen: Kiitettävän tason käyttöteoriassa opiskelijan tulee käsitellä aihealuetta kattavasti suhteuttaen tarkasteltava ilmiö laajempaan ammattialan viitekehykseen. Tämän lisäksi opiskelijan tulee käsitellä tietoa kriittisesti arvioiden ja perustella tekemänsä ratkaisut hyödyntämällä lähdemateriaalia, omaa asiantuntijuuttaan ja kokemuksellista tietoa. Tyydyttävän tasoinen käyttöteoria on silloin, kun opiskelija on pyrkinyt jäsentämään aihealuetta, mutta käsittely jää pinnalliseksi suhteessa ammattialaan. Opiskelija käsittelee lähdemateriaalia, omaa asiantuntijuuttaan ja kokemuksellista tietoa ilmiöstä irrallisena ja hänen taitonsa liittää eri tiedonlajeja toisiinsa on puutteellinen.
Opiskelija rajoittuu tarkastelemaan aihealuetta yhdestä, ristiriidattomasta näkökulmasta ja hän käyttää lähdemateriaalia ja kokemuksellista tietoa niukasti ja kritiikittömästi. Osa opiskelijoista koki vaikeana käyttöteoriansa itsearvioinnin, ennen kaikkea sen numeerisen arvioinnin.

Loppuseminaarissa opintojakson opettajat esittelivät opiskelijoille tekemänsä yhteenvedon näiden käyttöteorioista. Opintojakson aikana tuotetut käyttöteoriat jakaantuivat pääsääntöisesti kolmeen tasoon reflektoida ja aukikirjoittaa omaa toimintaa ohjaavat periaatteet. Seuraavassa on lyhyt kuvaus tasoista:

1) Käyttöteoriassa oli kattavaa oman toiminnan tarkastelua, mistä selvisi hyvin työtä ohjaava laajempi viitekehys ja asiantuntijuuden osa-alueet. Käyttöteoriassa oli kuvattu sitä, miten arvoja ja normeja sovelletaan omassa työssä sekä mikä niiden merkitys työssä on. Tekstissä oli runsaasti "minä" -muotoista kerrontaa, ja sekä alan toimintakäytänteisiin että omaan toimintaan liittyvää reflektiivistä ja kriittistä pohdintaa sekä vastauksia "miksi” - kysymyksiin. Lähdemateriaalia oli käytetty runsaasti.

2) Käyttöteoria oli sujuvaa kuvausta päivittäisestä työstä, lähinnä siitä mitä asiakkaiden tai potilaiden kanssa tehdään ja minkälaisia asioita ja toimintoja työssä tapahtuu. "Minä” -muotoista ilmaisua oli vähän. Toiminta oli kuvattu tarkasti, mutta sitä, mihin oma toiminta perustuu, ei oltu juurikaan kuvattu. Jonkin verran oli vastauksia “miten” -kysymyksiin. Joitakin relevantteja lähteitä oli käytetty.

3) Käyttöteoria sisälsi joko luettelonomaista kuvausta työpäivästä, tai niin runsasta kuvausta, että ydintä oli vaikea löytää tekstistä. Arvot, normit ja suositukset olivat kirjoitettu näkyviin, mutta niiden merkitystä omaa työtä ohjaavina tekijöinä oli kuvattu niukasti. Osittain oli käytetty abstraktilla tasolla olevia käsitteitä. Vastauksia "mitä” -kysymyksiin oli runsaasti. Lähdemateriaalia ei oltu käytetty hyväksi työtä tehdessä.

Kattavaan oman toiminnan arviointiin kyenneet aikuisopiskelijat kuvasivat metakognitioon ja oppimaan oppimiseen liittyviä asioita, havaiten esimerkiksi oman tietoperustansa puutteita, uusia oppimistarpeita ja tavoitteita. He kyseenalaistivat myös vallitsevia toimintatapoja ja niihin liittyviä taustaoletuksia. Samansuuntaisia tuloksi on saanut Liimatainen (2002) tutkiessaan opiskelijoiden terveyden edistämisen osaamisen kehittymistä terveysalan koulutuksen aikana. Edellä kuvatulle 
ensimmäiselle tasolle yltäneiden opiskelijoiden käyttöteorioiden kuvauksessa on kyetty pohtimaan asioita kriittisen reflektoinnin tasolla (Mezirow 1998). Opiskelijoiden kyetessä laadullisesti syvälliseen reflektioon, myös terveyden edistämistä koskevat skeemat ja merkitysperspektiivit muuttuvat ja saavat uusia merkityksiä. Itsesäätelytiedon ja reflektiotaidon kehittyminen on osoittautunut merkittäväksi tekijäksi terveyden edistämisen asiantuntijuuden kehittymisessä. (Liimatainen 2002.)

Aina työelämässä ei ole aikaa pysähtyä tarkastelemaan omien toimiensa rationaalisuutta ja toimivuutta, joten opintojakson tavoitteena olikin antaa opiskelijalle mahdollisuus kriittiseen itsetutkiskeluun. Sulautuva opetus tarjosi tähän välineitä. Vaikuttaa siltä, että opintojakson rakenteellinen monipuolisuus oli rikkaus, josta nimenomaan aikuiset opiskelijat saivat erilaisia näkökulmia oman toimintansa tarkasteluun. Vain tarkastelemalla omaa toimintaansa, sitä pystyy tavoitteellisesti muuttamaan. Tämä on mielekästä myös työhön liittyvän motivaation säilymisen kannalta (Hopia \& Heikkilä 2005). Käyttämällä hyväksi ryhmän kokemuksia ja näkökulmia mahdollistuu ajatusten jatkaminen ja kehittäminen myös niiltä osin, mihin yksilö ei yksin olisi pystynyt. Ryhmän hyödyntäminen onkin ehdottomasti tärkeä elementti kaikessa aikuisopiskelussa.

Opintojakson tavoitteena olleen osaamisen arvioimiseksi on tärkeä keskustella yhdessä opintojaksolla heränneistä ajatuksista sekä tehdä yhteenveto opintojakson tuottamasta ymmärryksestä. Asiantuntijuuden kehittymisessä tärkeää on itsensä ja oman toiminnan arviointi, joka kehittyy vain harjoittelemalla. Arvioimalla omaa käyttöteoriaansa sen kirjoittamisen aikana ja jälkeen, opiskelija joutuu tarkastelemaan omaa toimintaansa kriittisesti.

Asiantuntijuuden vahvistaminen ja siihen liittyvien innovaatioiden kehittäminen on tärkeää huomioida myös tutkimuksellisesti, sillä asiantuntijuuden vahvistaminen liittyy olennaisesti elinikäisen oppimisen ideologiaan. Uusien pedagogisten menetelmien tutkimusta tarvitaan, jotta erityisesti työssäkäyvien aikuisten ammattilaisten asiantuntijuuden oikeanlaiseen "ravisteluun” ja asioiden tiedostamiseen löytyisi testattuja välineitä.

\section{Lähteet}

Argyris, C. \& Schön, D. A. (1974). Theory in practice: increasing professional effectiveness. Jossey-Bass Publishers.

Asetus Ammattikorkeakouluista annetun valtioneuvoston asetuksen muuttamisesta. 16.6.2005. (423/2005)

Bereiter, C. \& Scardamalia, M. (1993). Surpassing ourselves. An Inquiry into the nature and implications of expertise. Open Court.

Bersin J. (2004). The Blended Learning Book: Best Practices, Proven Methodologies, and Lessons Learned (excerpt). Pfeiffer Wiley. http://media.wiley.com/product_data/excerpt/67/07879729/0787972967.pdf (Luettu: 27.9.2007).

Business Arena Oy. Learning Cafe ${ }^{\circledR}$ uuden tiedon synnyttämisen työkaluna. http:// www.businessarena.fi/oppivat_alueet/ learningcafe.htm (Luettu: 27.9.2007)

Hopia, H. \& Heikkilä, J. (2005). Vahvistumista ja luopumista: aikuiskoulutuksessa opiskelevien sairaanhoitajien ammatillinen kasvu ja siihen yhteydessä olevat tekijät ammattikorkeakoulutuksen aikana. Hoitotiede 17, 178-188.

Kauppinen, R. A. (2007). Ihmisen tapa oppia. PS-kustannus.

Levonen, J. (2007). Johdanto. Teoksessa: Levonen, J. (toim.) Ylempi ammattikorkeakoulututkinto - Työelämälähtöistä asiantuntemusta kehittämässä. Hämeen ammattikorkeakoulu, 5-10.

Liimatainen, L. (2002). Kokemuksellisen oppimisen kautta kohti terveyden edistämisen asiantuntijuutta. Hoitotyön ammattikorkeakouluopiskelijoiden terveyden edistämisen oppiminen hoitotyön harjoittelussa. Studies in Sport, Physical Education and Health, 90. University of Jyväskylä.

Littlejohn, A. \& Pegler, C. (2007). Preparing for blended learning. Routledge.

Malinen, A. (2000). Towards the essence of adult experiential learning. A reading of the theories of Knowles, Kolb, Mezirow, Revans and Schön. University of Jyväskylä.

Mezirow, J. (1998). On critical reflection. Adult Education Quarterly 48, 185-198.

Nonaka, I.\& Takeuchi, H. (1995). The knowl- 
edge-creating company: how Japanese companies create the dynamics of innovation. Oxford University Press.

Ojanen, S. (2003). Ohjauksesta oivallukseen ohjausteorian kehittelyä. Teoksessa Silkelä, R. (toim.) Tutkimuksia opetusharjoittelun ohjauksesta. Suomen harjoittelukoulujen vuosikirja n:o 1, 11-22.

Onnismaa, J. (2007). Ohjaus- ja neuvontatyö. Aikaa, huomiota ja kunnioitusta. Gaudeamus.

Opetushallitus 2008. Monimuoto-opetus. http:// www.edu.fi/tonet/fin/linkit/sanasto_op.html. (Luettu: 4.2.2008)

Sit, J. W. H., Chung, J. W. Y., Chow, M. C. M. \& Wong, T. K. S. (2004). Experiences of online learning: students’ perspective. Nurse Education Today 25, 140-147.

Stubbs, M., Martin, I. \& Endlar, L. (2006). The structuration of blended learning: putting holistic design principles into practice. British Journal of Educational Technology 37, 163-175.

Terveyden edistämisen laatusuositus. 2006. www.stm.fi (Luettu: 4.2.2008)

The World Café Community. http:// www.theworldcafe.com/ (Luettu: 27.9.2007)

Twomey, A. (2004). Web-based teaching in nursing: lessons from the literature. Nurse Education Today 24, 452-458.

Tynjälä, P. (1999). Towards expert knowledge? A comparison between constructivist and a traditional learning environment in the University. International Journal of Education-al Research 31, 357-442. 